\title{
Phytosociology of snowbed and exposed ridge vegetation of Svalbard
}

\author{
Michał Węgrzyn ${ }^{1} \cdot$ Paulina Wietrzyk ${ }^{1}$
}

Received: 16 July 2014/Revised: 27 June 2015 / Accepted: 29 June 2015 / Published online: 11 July 2015

(C) The Author(s) 2015. This article is published with open access at Springerlink.com

\begin{abstract}
Arctic vegetation still lacks a uniform system to classify its plant communities, the current arrangement of the phytosociological data being difficult to interpret. However, using modern methods, it has proved possible to organize the current data to create a suitable system based on numerical algorithms (detrended correspondence analysis and cluster analysis) and traditional methods for 135 phytosociological relevés from snowbed and exposed ridge habitats of Svalbard; 125 relevés were selected from twentieth and early twenty-first century publications, and ten relevés were collected by our group in 2012 from the Kaffiøyra Plain (Oscar II Land, NW Spitsbergen). Our analysis has shown there to be four associations and one community. Two associations and one community are distinguished within the Luzulion arcticae Gjærev. 1950: (1) the Pedicularietum hirsutae ass. nov., (2) the Deschampsietum alpinae (Nordh. 1943) Węgrzyn and Wietrzyk 2015 stat. nov., and (3) the Minuartia biflora community. Two syntaxa were assigned to the Luzulion arcuatae Elvebakk ex Węgrzyn and Wietrzyk 2015: (4) the Anthelietum juratzkanae Kobayashi ex Węgrzyn and Wietrzyk 2015 with a confirmed status and (5) the Gymnomitrietum coralloidis Hadač ex Węgrzyn and Wietrzyk 2015 stat. nov. was described by means of a new approach.
\end{abstract}

Michał Węgrzyn

michal.wegrzyn@uj.edu.pl

Paulina Wietrzyk

paulina.wietrzyk@doctoral.uj.edu.pl

1 Prof. Z. Czeppe Department of Polar Research and Documentation, Institute of Botany, Jagiellonian University, Kopernika 27, 31-501 Kraków, Poland
Keywords Arctic - Luzulion arcuatae $\cdot$ Luzulion arcticae $\cdot$ Numerical classification · Syntaxonomy

\section{Introduction}

Since the beginning of exploration of northern polar regions, researchers have paid special attention to the Arctic vegetation as being one of the most sensitive components of the polar terrestrial ecosystems. In the recent decades, rapid response of Arctic vegetation to the ongoing climate change has been observed (Stow et al. 2004; Jónsdóttir 2005; Węgrzyn et al. 2011; Olech et al. 2011). Observing these changes appears to be easy due to the simplicity of the species composition of plant communities, but despite the relatively small number of species forming the tundra, Arctic vegetation still lacks a complete, uniform, and transparent system that will classify all the communities in terms of the classical plant phytosociology (Braun-Blanquet 1964; Walker et al. 1994; Nilsen and Thannheiser 2013).

Considerable attention to phytosociological research has been paid regarding the Svalbard flora in comparison with other elements of the Arctic vegetation (Elvebakk and Prestrud 1996; Rønning 1996; Walker et al. 2005). Although botanical research of Svalbard has been undertaken since the eighteenth century, it has solely consisted of describing new species and documenting their location (Nilsen and Thannheiser 2013). The first description of the Svalbard plant habitats was by Elton and Summerhayes (1928), and the oldest phytosociological study of the Svalbard tundra was conducted by Hadač (1946). After 1950 , the vegetation of the archipelago was mainly examined by Rønning (1965), Eurola (1968), Philippi (1973). In subsequent years, phytosociological studies were 
continued by Brattbakk (1980), Hartmann (1980), Dubiel and Olech (1990), Möller and Thannheiser (1997), Nilsen et al. (1999), and Möller (2000). The characteristics of the plant community habitats in Svalbard were studied by Elvebakk (1994, 2005), and in a broader sense, Walker et al. (1994) assigned the circumpolar vegetation communities to specific habitat types; however, several phytosociological problems emerged in these two mentioned papers, one of which is the assignment of Luzulion arcuatae Elvebakk ex Węgrzyn and Wietrzyk 2015 to various habitats. Elvebakk (1994) assigned it to snowbed and exposed ridge and Walker et al. (1994) to polar desert and scree vegetation. From the standpoint of environmental factors, scree vegetation can be considered as exposed ridge, but snowbed is a completely different type of habitat (Elvebakk 1994). The current arrangement of phytosociological data available in the literature is perplexing, and researchers have ran into numerous problems when trying to employ it (Nilsen and Thannheiser 2013). Such problems result from (1) the usage of different phytosociological systems, (2) the usage of different size of area of the relevés, (3) the questioned representativeness of the results of phytosociological research for the whole area of Svalbard, (4) the omission of cryptogamic species (mainly lichens), and (5) not taking into account the cryptogamic species as character species of syntaxa, although they are the main element of tundra vegetation. Researchers who have recently attempted to order the phytosociological system of the Spitsbergen communities still show the large gaps existing in Arctic vegetation data (Nilsen and Thannheiser 2013).

Our studies relating to these problems are based on a detailed analysis of our own data and those found in twentieth and early twenty-first century literature by organizing and standardizing information on syntaxa assigned to the snowbed and the exposed ridge. In 2012, a phytosociological study was conducted in the Kaffiøyra Plain (NW Spitsbergen) which is $15 \mathrm{~km}$ long and varies in width from 1.5 to $4 \mathrm{~km}$. It is restricted on the eastern side by a mountain range massive in the central part of Oscar II Land and on the western side by Forlandsundet. In the south, its natural boundary is the Dahl glacier, and in the north, it is surrounded by Hornbaekbukta Bay, Aavatsmark glacier, and Dahlbrebukta Bay with the Farmsundet Passage. Seven glaciers come down to the plain from the mountain region. Kaffiøyra Plain is homogenous in terms of vegetation, but erosion processes caused by glacier rivers over the entire terrace area are highly visible (Sobota and Lankauf 2010).

The results initiated a detailed phytosociological analysis of alliances and associations related to the snowbed and exposed ridge. These types of habitats were described by Elvebakk (1994). Ordering the data and creating the hierarchical classification of tundra communities associated with snowbed and exposed ridge were undertaken in accordance with the Zurich-Montpellier School of Phytosociology (Braun-Blanquet 1964) and supported by numerical methods (Sokal and Michener 1958; Hill and Gauch 1980).

\section{Materials and methods}

Our studies, based on 10 of our own relevés and 125 relevés from the literature (Table 1), were analysed by phytosociological and numerical methods.

In July 2012, ten phytosociological relevés (each of $1 \mathrm{~m}^{2}$ area) were taken in the Kaffiøyra plain. The location of each relevé was determined in accordance with the cardinal principle of selecting a uniform and homogenous plant community surface (Braun-Blanquet 1964). The list of species of vascular plants, bryophytes, lichens, and cyanobacteria was obtained for each relevé. Additionally, the degree of cover-abundance and the sociability for each species were defined (Braun-Blanquet 1964). Taxa which were difficult to identify and fragments of biological soil crusts were collected for further determination in the laboratory. All material has been deposited in the Herbarium of the Institute of Botany of the Jagiellonian University in Kraków (KRA).

The 125 relevés selected from publications referred to plant communities that Elvebakk (1994) assigned to two alliances: the Luzulion arcticae Gjærev. 1950 and the $L$ arcuatae Elvebakk ex Węgrzyn and Wietrzyk 2015 (Table 1). The analysed dataset also contained relevés of other plant communities that have a high degree of similarity in relation to those previously mentioned (Table 1). Selection was necessary because many citations, despite describing new syntaxa, did not contain the required phytosociological data (Elvebakk 1994; Weber et al. 2000); these refer to four of the communities listed in Table 1: the Salix polaris-Cetraria delisei com. Hadač 1989, the Saxifraga oppositifolia-Cetraria delisei com. Elvebakk 1985, the Cetraria delisei com. Mattick 1949 and the "rødsildre lavmark" com. Brattbakk 1979. A second problem encountered during the selection process resulted from omitting or grouping together epilithic and soil lichens by some authors for two communities: the Saxifraga oppositifolia com. Möller 2000 and the Cetrarietum delisei Möller 2000. Furthermore, only relevés having an area of 1-10 $\mathrm{m}^{2}$ were employed for the analysis. Therefore, the relevés of the Cetraria delisei com. Brossard et al. 1984, the Cetraria delisei-Saxifraga oppositifolia com. Nimis 1985, and Saxifraga oppositifolia com. Dubiel and Olech 1990 with a plot area of only $0.01 \mathrm{~m}^{2}$ were omitted, as were the relevés of "community C" com. Barkman 1987, 
Table 1 The list of plant communities and associations associated with the snowbed and exposed ridge habitats

\begin{tabular}{|c|c|c|c|c|}
\hline Community & Authors, year & Localization & $\begin{array}{l}\text { Number } \\
\text { of relevés }\end{array}$ & $\begin{array}{l}\text { Numbering of relevés } \\
\text { in the data analyses }\end{array}$ \\
\hline \multicolumn{5}{|l|}{ Included in the statistical analyses } \\
\hline "Community of Kaffiøyra Plain" & Own data, Jul. 2012 & 1 & 10 & $1-10$ \\
\hline "Polar barren desert" com. & Gjessing and Øvstedal (1975) & 2 & 5 & $11-15$ \\
\hline $\begin{array}{l}\text { Cerastium arcticum-Anthelia juratzkana } \\
\text { com. }\end{array}$ & Hadač (1989) & 9,10 & 3 & $16-18$ \\
\hline $\begin{array}{l}\text { Pedicularis hirsutae-Gymnomitrietum } \\
\text { coralloidis }\end{array}$ & Hadač (1989) & 10,11 & 3 & $19-21$ \\
\hline Luzulo confusae-Salicetum polaris & Hadač (1989) & $5,6,7,8,10$ & 7 & $22-28$ \\
\hline Gymnomitrietum coralloidis prov. & Hadač (1946) & 4 & 1 & 29 \\
\hline Solorineto-Salicetum polaris prov. & Hadač (1946) & 4 & 1 & 30 \\
\hline $\begin{array}{l}\text { Saxifragetum caespitosae, subass: } \\
\text { Oncophorus wahlenbergii prov. }\end{array}$ & Kobayashi et al. (1990) & 3 & 3 & $31-33$ \\
\hline Cetraria delisei com. & Dubiel and Olech (1990) & 12,13 & 15 & $34-48$ \\
\hline Saxifraga nivalis com. & Dubiel and Olech (1990) & 14 & 6 & $49-54$ \\
\hline Ranunculus gracilis com. & Dubiel and Olech (1990) & 15 & 2 & $55-56$ \\
\hline $\begin{array}{l}\text { Saxifraga oppositifolia-Cetraria delisei } \\
\text { norw.: "rødsildre lavhei" com. }\end{array}$ & Brattbakk (1986) & 2 & 4 & $57-60$ \\
\hline $\begin{array}{l}\text { Saxifraga oppositifolia-Drepanocladus } \\
\text { uncinatus com. }\end{array}$ & Hjelmstad (1981) & 16 & 5 & $61-65$ \\
\hline $\begin{array}{l}\text { Saxifraga oppositifolia-Cetraria delisei } \\
\text { norw.: "moserikt" com. (community in } \\
\text { which bryophytes are dominant) }\end{array}$ & Hermansen (1979) & 2 & 10 & $66-75$ \\
\hline $\begin{array}{l}\text { Saxifraga oppositifolia-Cetraria delisei } \\
\text { norw.: "lavrikt" com. (community in } \\
\text { which lichens are dominant) }\end{array}$ & Hermansen (1979) & 2 & 20 & $76-95$ \\
\hline $\begin{array}{l}\text { Cetraria delisei-Saxifraga oppositifolia } \\
\text { com. }\end{array}$ & Elvebakk (1979) & 2 & 40 & $96-135$ \\
\hline \multicolumn{5}{|l|}{ Not included in the statistical analyses } \\
\hline Salix polaris-Cetraria delisei com. & Hadač (1989) & & No relevés & \\
\hline $\begin{array}{l}\text { Saxifraga oppositifolia-Cetraria delisei } \\
\text { com. }\end{array}$ & Elvebakk (1985) & & No relevés & \\
\hline Cetraria delisei com. & Mattick (1949) & & No relevés & \\
\hline $\begin{array}{l}\text { "Rфdsildre lavmark" com. (=“rødsildre } \\
\text { lavhei") }\end{array}$ & Brattbakk (1979) & & No relevés & \\
\hline Saxifraga oppositifolia com. & Möller (2000) & & 6 & - \\
\hline Cetrarietum delisei & Möller (2000) & & 10 & - \\
\hline Cetraria delisei com. & Brossard et al. (1984) & & 8 & - \\
\hline $\begin{array}{l}\text { Cetraria delisei-Saxifraga oppositifolia } \\
\text { com. }\end{array}$ & Nimis (1985) & & 69 & - \\
\hline Sagifraga oppositifolia com. & Dubiel and Olech (1990) & & 3 & - \\
\hline "Community C" com. & Barkman (1987) & & 3 & - \\
\hline
\end{tabular}

Data are taken from existing literature. Additionally, data for the relevés from the Kaffiøyra Plain are given

one relevé of Luzulo confusae-Salicetum polaris Hadač 1989, and two relevés of Saxifraga nivalis com. Dubiel and Olech 1990 since their areas were too large $\left(12-100 \mathrm{~m}^{2}\right)$. The localities of selected and analysed relevés are marked on the map of Svalbard (Fig. 1).

The species of vascular plants, bryophytes, and lichens, whose presence was highly questionable, were deleted from the dataset. Cyanobacteria species were not included in the analysis because the majority of other authors also did not take them into account.

In the case of phytosociological tables with a coverabundance scale other than that of Braun-Blanquet (1964), the scale was changed to allow a compilation of relevés in phytosociological analyses using the numerical methods in 


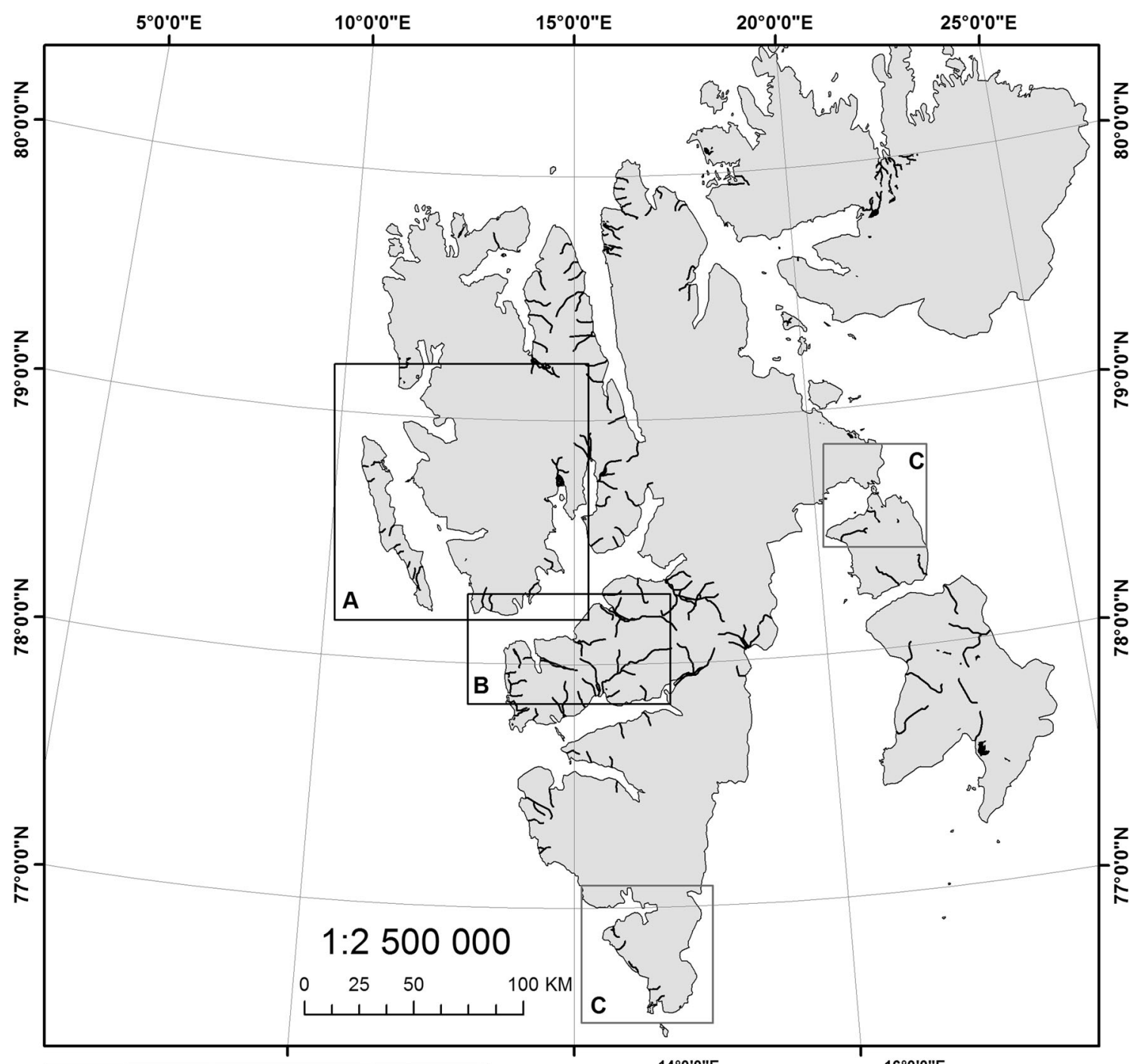

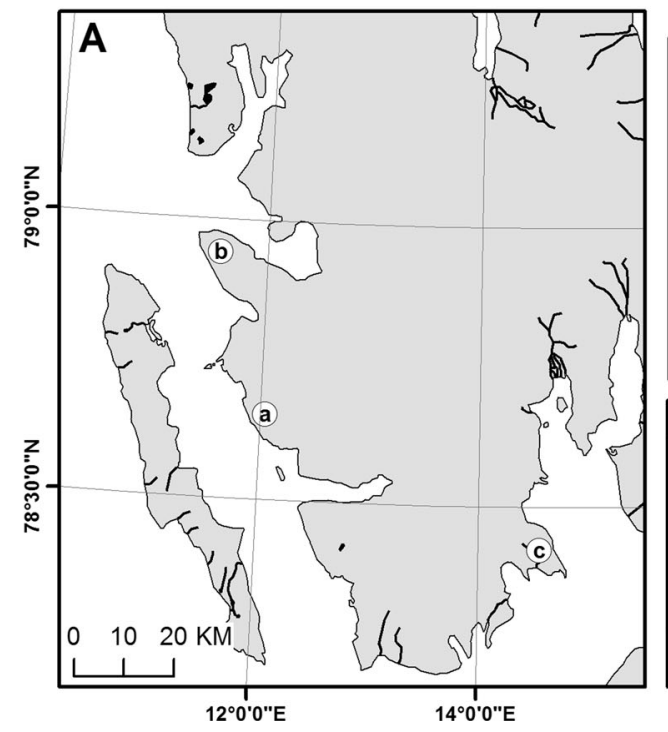

Fig. 1 The localization of relevés used in the data analyses: $a-$ Kaffiøyra Plain, $b$-Brøggerhalvøya, $c$-Bohemanflya, $d$-Arnicadalen, $e$-Verdeborgsletta, $f$-Linnédalen, $g$-Kongressdalen, $h-$

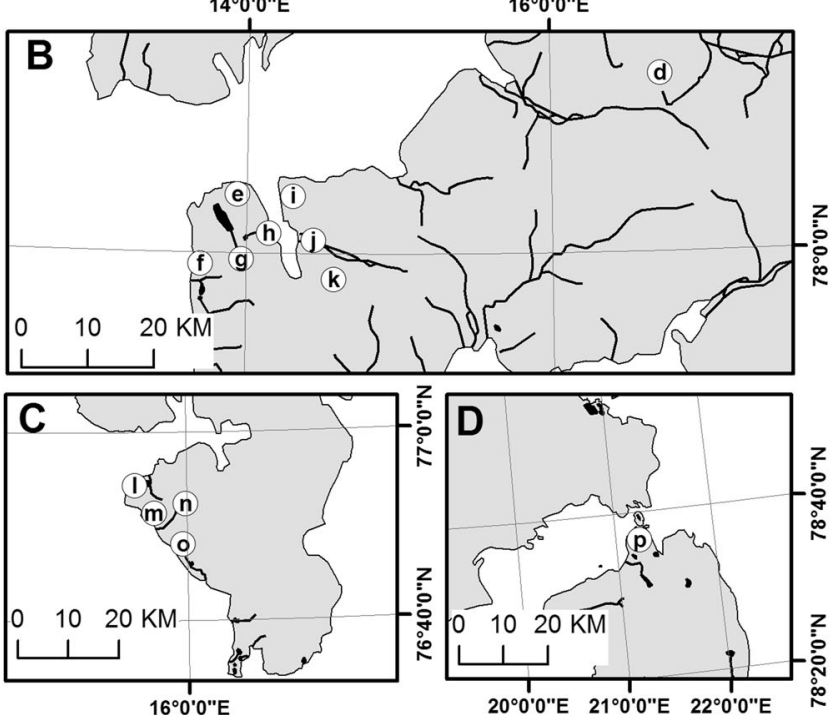

Minervaodden, $i$-Bykollen, $j$-Grønfjordfjellet, $k-$ Grøndalen, $l-$ Palffyodden, $m$-Hornsundneset, $n-$ Sergeevfjellet, $o-$ Breinesflya, $p$-Frankenhalvoya 
programs: TURBOVEG (Hennekens 2012) and JUICE (Tichý and Holt 2006).

Detrended correspondence analysis (DCA) was done in the CANOCO 4.5 (Lepš and Šmilauer 2003) in order to extract the groups of similar relevés (Hill and Gauch 1980). Cluster analysis was performed using the flexible UPGMA (flexible unweighted pair group method with arithmetic mean, $\beta=0.15$ ) in SYN-TAX 2000 (Podani 2001). The goal here was to show similarity between relevés (Sokal and Michener 1958). In order to perform the above-mentioned analyses, the cover-abundance scale proposed by van der Maarel (1979) was used.

For all the alliances and associations separated in the data analyses, a synthetic table containing the constancy and fidelity for each species was made using two programs: TURBOVEG 2000 (Hennekens 2012) and JUICE (Tichý and Holt 2006). Based on these results, the character and companion species were defined (Braun-Blanquet 1964). Nomenclature of syntaxa followed the "International Code of Phytosociological Nomenclature" (Weber et al. 2000).

The last stage of the analysis was to prepare the phytosociological table describing the vegetation occurring in the Kaffiøyra Plain. This was made on the basis of ten relevés using TURBOVEG 2000 (Hennekens 2012) and JUICE (Tichý and Holt 2006) software.
The nomenclature of vascular plants, bryophytes, lichens, and cyanobacteria is according to Elvebakk and Prestrud (1996), The Plant List (2013), MycoBank (2014).

\section{Results}

As a result of the DCA, the 135 relevés are divided into two groups, graphically presented in the ordination, both of which are correspond to revised alliances (Fig. 2). In the first group (L. arcticae Gjærev. 1950), 88 relevés represented by the following communities occur: the "community of the Kaffiøyra Plain", the Saxifraga oppositifoliaCetraria delisei "moserikt" com. Hermansen 1979, the Saxifraga oppositifolia-Cetraria delisei com. "lavrikt" Hermansen 1979, the "polar barren desert" com. Gjessing and Øvstedal 1975, the Cetraria delisei-Saxifraga oppositifolia com. Elvebakk 1979, the Saxifraga oppositifoliaCetraria delisei "rødsildre lavhei" com. Brattbakk 1986.

The second group (L. arcuatae Elvebakk ex Węrzyn and Wietrzyk 2015) includes 47 relevés. They belong to other communities, namely the Cerastium arcticum-Anthelia juratzkana com. Hadač 1989, the Pedicularis hirsutae-Gymnomitrietum coralloidis Hadač 1989, the Luzulo confusaeSalicetum polaris Hadač 1989, the G. coralloidis Hadač
Fig. 2 Detrended correspondence analysis (DCA) scatterplot of 135 relevés (numbers) along the first and second ordination axes. Two groups of relevés were distinguished: the L. arcticae Gjærev. 1950 and the $L$. arcuatae Elvebakk ex Wegrzyn and Wietrzyk 2015

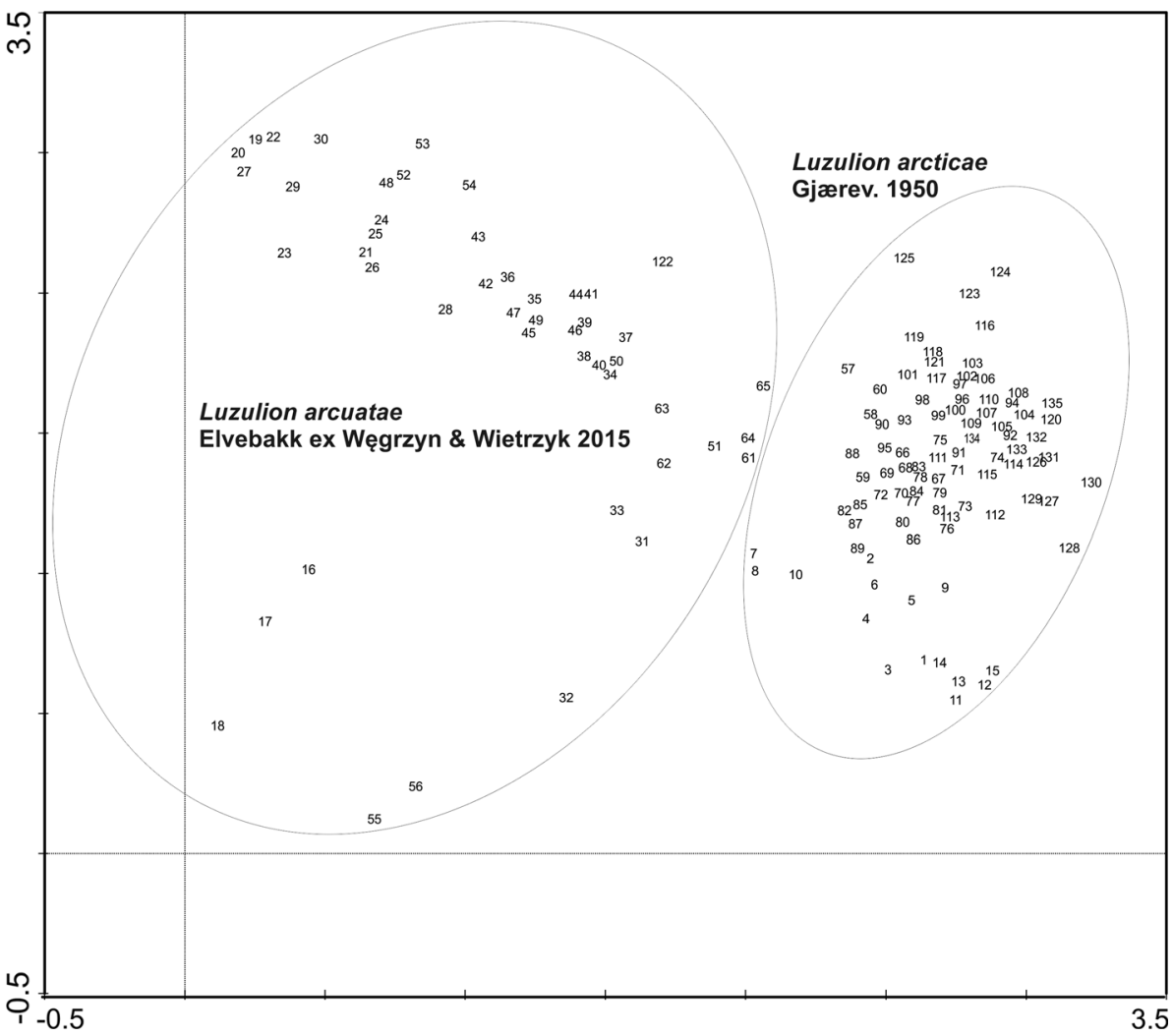




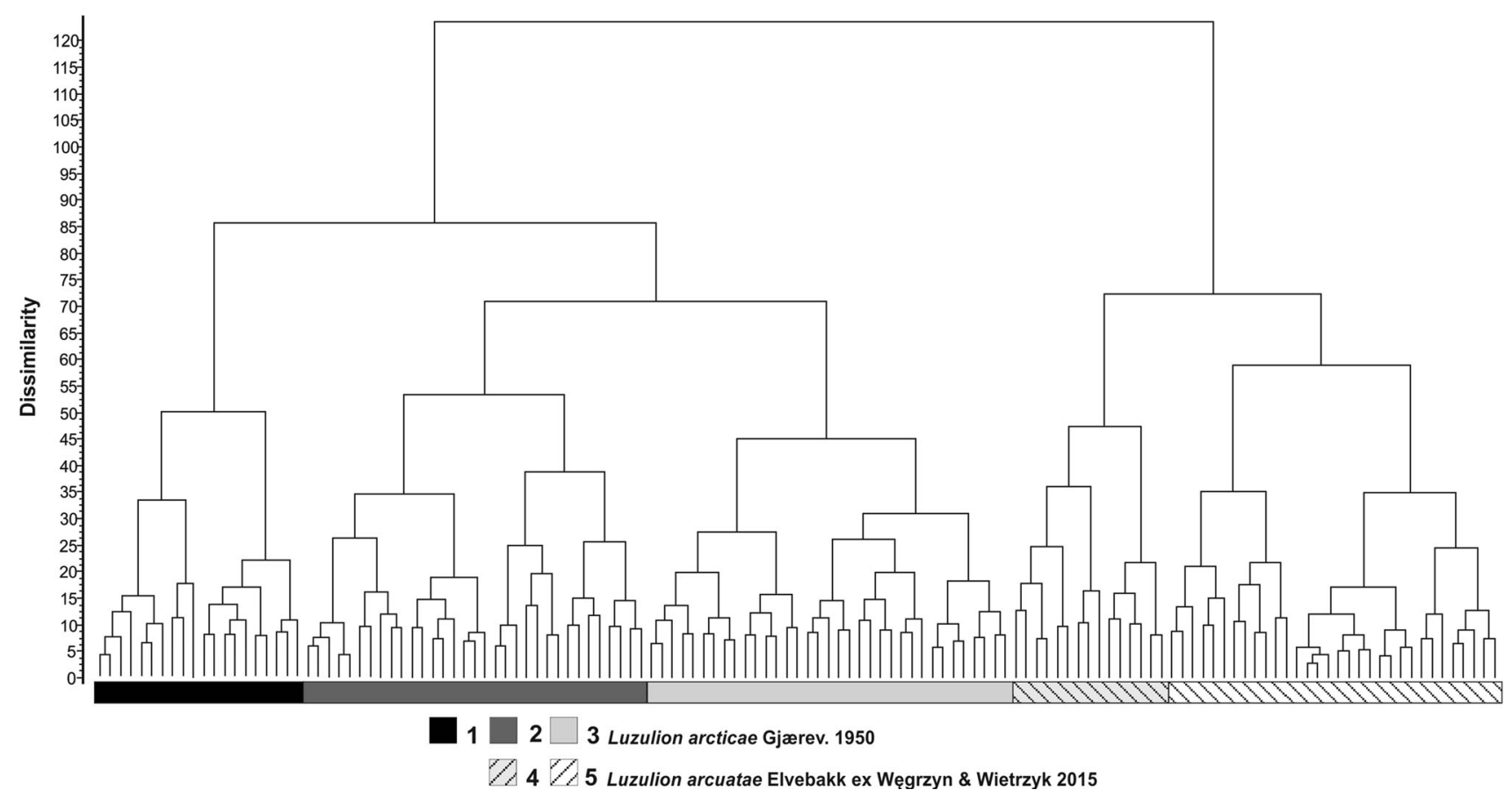

Fig. 3 Dendrogram classifying the 135 relevés. The type of shading refers to particular association (1-5). Numbers 1-3 correspond to the L. arcticae Gjærev. 1950 and numbers $4-5$ to the L. arcuatae Elvebakk ex Węgrzyn and Wietrzyk 2015. Following associations

1946 prov., the Solorineto-Salicetum polaris Hadač 1946 prov., the Saxifragetum cespitosae, the subassociation of Oncophorus wahlenbergii Kobayashi 1988 prov. (Kobayashi et al. 1990), the Cetraria delisei com. Dubiel and Olech 1990, the Saxifraga nivalis com. Dubiel and Olech 1990, the Ranunculus gracilis com. Dubiel and Olech 1990, and the Saxifraga oppositifolia-Drepanocladus uncinatus com. Hjelmstad 1981; one relevé (no. 122) belongs to the Cetraria delisei-Saxifraga oppositifolia com. Elvebakk 1979.

In order to confirm the above ordination (Fig. 2), a cluster analysis was performed, which results in a dendrogram that groups all relevés into clusters (Fig. 3). This analysis confirmed the division of the analysed relevés into two groups, equal to alliances; within these groups, five associations were distinguished (Fig. 3).

After grouping the syntaxa with numerical methods (Figs. 2, 3), they were analysed with a phytosociological method. Table 2 classifies all obtained syntaxa based on the degree of constancy and fidelity of species of vascular plants, bryophytes, and lichens. Relevés belonging to the $L$. arcticae Gjærev. 1950 were grouped into two associations and one community. The Minuartia biflora community and the Pedicularietum hirsutae ass. nov. are described for the first time (Tables 2 and 3; Fig. 3). The third one, Deschampsietum alpinae (Nordh. 1943) Wegrzyn and Wietrzyk 2015 stat. nov., has a new phytosociological status (Table 2; Fig. 3). were distinguished: $1-M$. biflora community; $2-D$. alpinae (Nordh. 1943) Węgrzyn and Wietrzyk 2015 stat. nov.; 3-P. hirsutae ass. nov.; 4-A. juratzkanae Kobayashi ex Węgrzyn and Wietrzyk 2015; 5-G. coralloidis Hadač ex Węgrzyn and Wietrzyk 2015 stat. nov

Two plant communities were classified into the $M$. biflora community: the "community of the Kaffiøyra Plain" and the Saxifraga oppositifolia-Cetraria delisei "moserikt" com. Hermansen 1979. The similarity between these relevés resulted from the participation of such species as: Lecidea ramulosa Th. Fr., Juncus biglumis L., M. biflora (L.) Schinz \& Thell., Dicranoweisia crispula (Hedw.) Milde, Saxifraga hieracifolia Waldst. \& Kit. ex Willd. and Draba micropetala Hook.; the last four species were considered as differential species for the community (Table 2; Fig. 3.).

The relevés of the Cetraria delisei-Saxifraga oppositifolia com. Elvebakk 1979 (partially) and the Saxifraga oppositifolia-Cetraria delisei "lavrikt" com. Hermansen 1979 were grouped into one association, called $P$. hirsutae ass. nov. Within this association, relevé number 9 of the Saxifraga oppositifolia-Cetraria delisei "lavrikt" com. Hermansen 1979 was chosen as a nomenclatural type for this association. The distinguishing feature of these relevés is the presence of the subsequent character species: $P$. hirsuta L., Lecanora epibryon (Ach.) Ach., Minuartia rubella (Wahlenb.) Hiern, Carex misandra R.Br., Equisetum variegatum Schleich. ex F. Weber \& D. Mohr, and Solorina bispora Nyl. (Table 2; Fig. 3). The first two species have the highest degree of fidelity (IV) and are the most frequent in the species composition of the association.

The next distinguished association, D. alpinae (Nordh. 1943) Węgrzyn and Wietrzyk 2015 stat. nov., is 
Table 2 A synthetic table containing the species of vascular plants, bryophytes, and lichens

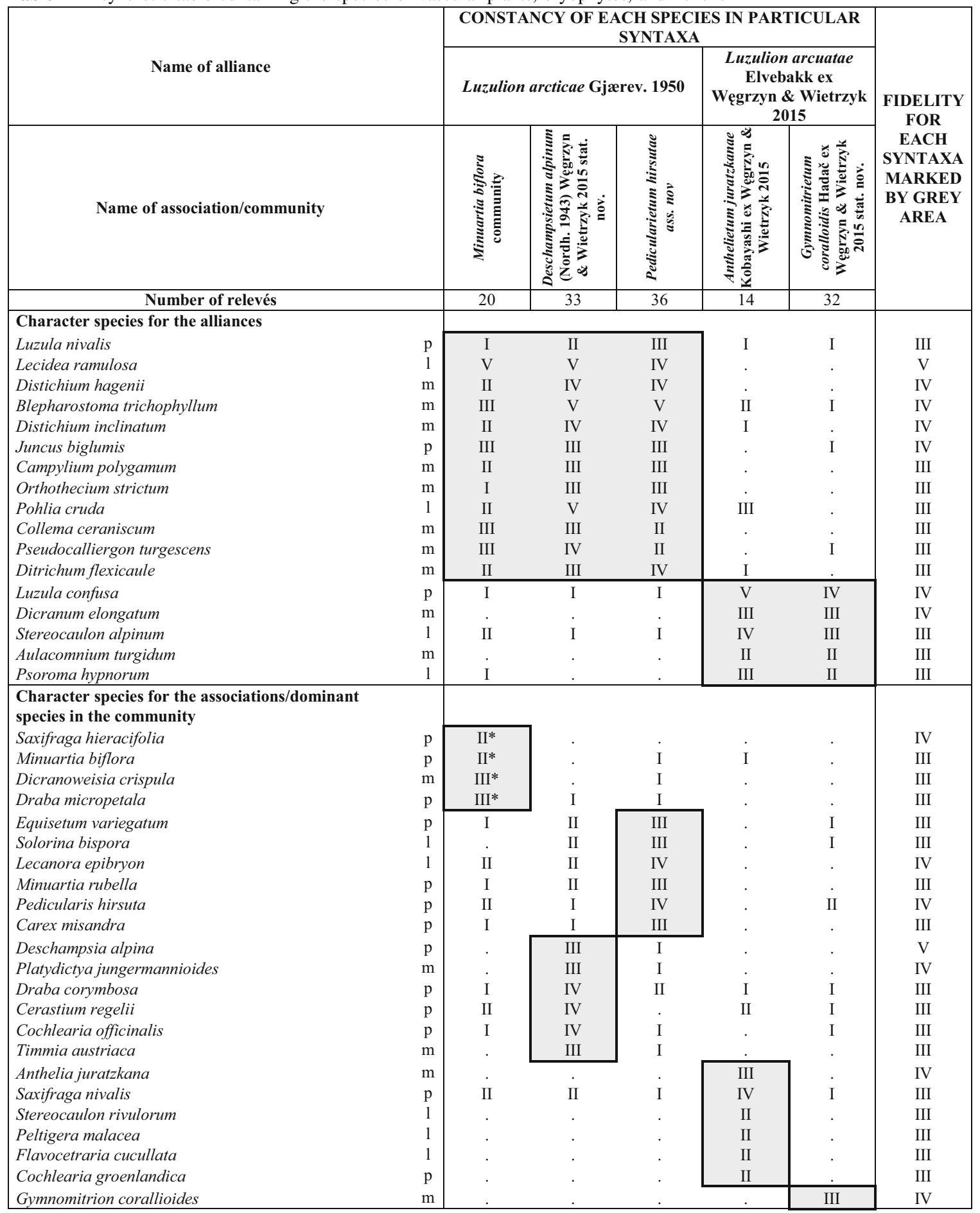

Common species: Vascular plant: Cerastium arcticum, Salix polaris, Saxifraga cernua, S. cespitosa, S. oppositifolia; Mosses: Brachythecium glaciale, Polytrichastrum alpinum; Lichens: Cetrariella delisei, Ochrolechia frigida, Cetraria islandica

The ordering is based on the degree of constancy and fidelity within each syntaxon. The characteristic species of alliances and associations are listed, and their constancy value is marked by grey area. Additionally, the common species within both habitats (snowbed and exposed ridge) are presented below the table. The letters (p, m, l) in the table mean the species identification: $p$-vascular plant; $m$ —-moss; $l$-lichen. The "constancy" represents the frequency of each species in all relevés of particular syntaxa. The "fidelity" means the species suitability as characteristic taxa for particular syntaxa, and it is based on the constancy level. The asterisk (*) marked the differential species in the Minuartia biflora community

Common species: Vascular plant: Cerastium arcticum, Salix polaris, Saxifraga cernua, S. cespitosa, S. oppositifolia; Mosses: Brachythecium glaciale, Polytrichastrum alpinum; Lichens: Cetrariella delisei, Ochrolechia frigida, Cetraria islandica 


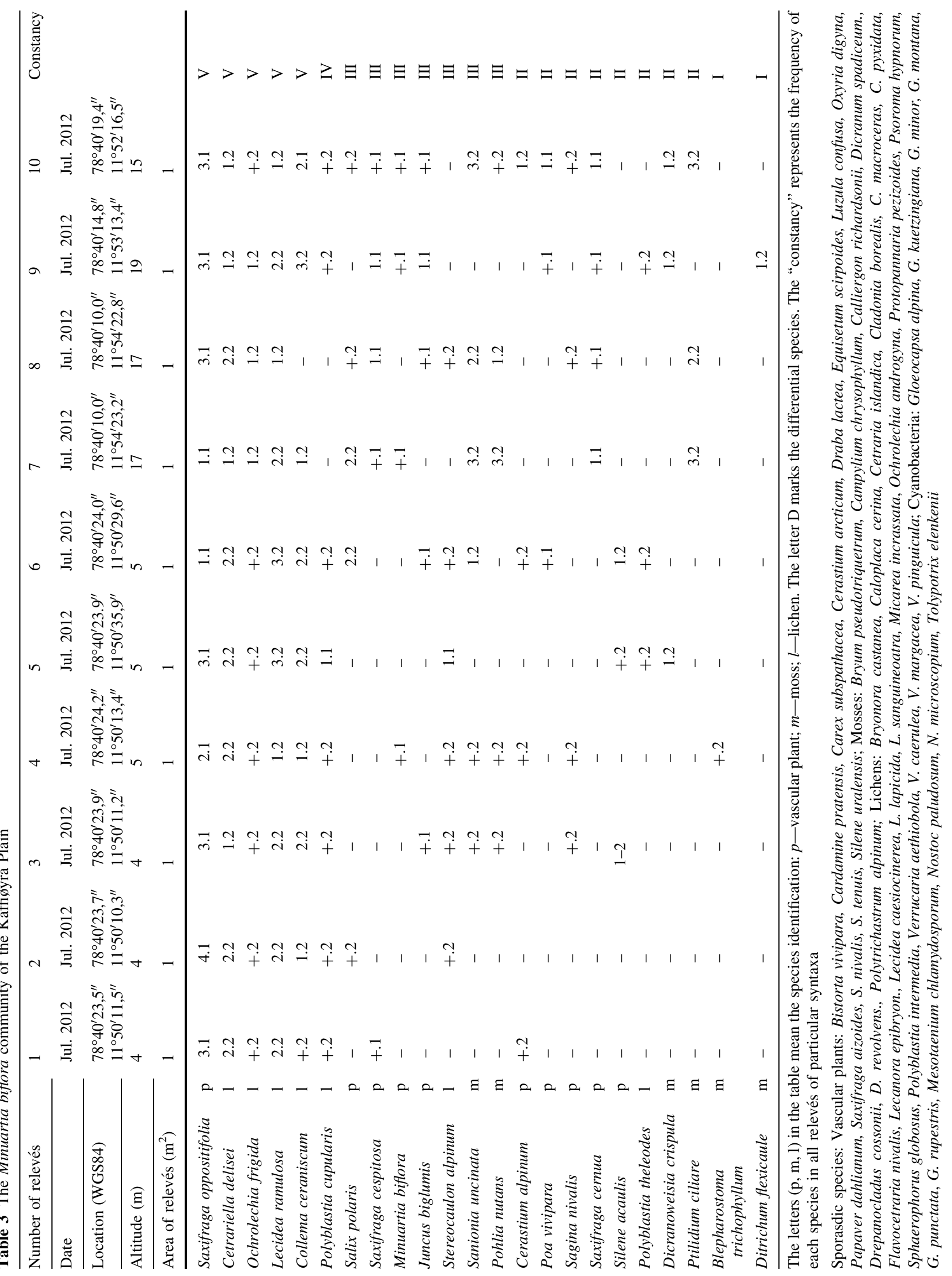


represented by the "polar barren desert" com. Gjessing and Øvstedal 1975, the Saxifraga oppositifolia-Cetraria delisei "rodsildre lavhei" com. Brattbakk 1986, and the Cetraria delisei-Saxifraga oppositifolia com. Elvebakk 1979 (partially). In the relevés of this association, apart from common bryophytes such as Platydictya jungermannioides (Brid.) H.A. Crum (fidelity degree: IV), and Timmia austriaca Hedw. (fidelity degree: III), the grass Deschampsia alpina (L.) Roem. \& Schult. (one of the character species of the association) has the largest frequency (fidelity degree: V); other character species of the association are Draba corymbosa R.Br. ex DC., Cerastium regelii Ostenf., and Cochlearia officinalis L. (Table 2; Fig. 3.).

Relevés within the $L$. arcuatae Elvebakk ex Węgrzyn and Wietrzyk 2015 were assigned to the Anthelietum juratzkanae Kobayashi ex Węgrzyn and Wietrzyk 2015 and to the G. coralloidis Hadač ex Węgrzyn and Wietrzyk 2015 stat. nov. After this study, the phytosociological status of the second syntaxon has changed.

The relevés of five communities are representative for the A. juratzkanae Kobayashi ex Węgrzyn and Wietrzyk 2015: the Saxifragetum cespitosae, the subassociation of the Oncophorus wahlenbergii Kobayashi 1988 prov. (Kobayashi et al. 1990), the Saxifraga nivalis com. Dubiel and Olech 1990, the Ranunculus gracilis com. Dubiel and Olech 1990, the Cerastium arcticum-Anthelia juratzkana com. Hadač 1989, and relevé no. 122 from the Cetraria delisei-Saxifraga oppositifolia com. Elvebakk 1979 (partially). The presence of Anthelia juratzkana (Limpr.) Trevis. (fidelity degree: IV) in the relevés was the main factor that supported their similarity. Except Anthelia juratzkana, other character species of the association include: Saxifraga nivalis L., Stereocaulon rivulorum H. Magn., Peltigera malacea (Ach.) Funck, Flavocetraria cucullata (Bellardi) Kärnefelt and A. Thell, and Cochlearia groenlandica L. (Table 2; Fig. 3).

The following communities have been classified into the G. coralloidis Hadač ex Węgrzyn and Wietrzyk 2015 stat. nov.: the P. hirsutae-G. coralloidis Hadač 1989, the Luzulo confusae-Salicetum polaris Hadač 1989, the G. coralloidis Hadač 1946 prov., the Solorineto-Salicetum polaris Hadač 1946 prov., the Cetraria delisei com. Dubiel and Olech 1990, and the Saxifraga oppositifolia-Drepanocladus uncinatus com. Hjelmstad 1981. The common occurrence of the Gymnomitrion corallioides Nees (the character species of the association) was the factor that supported the similarity of the relevés belonging to this association (Table 2; Fig. 3).

The statistical and phytosociological analyses (Figs. 2, 3; Table 2) characterized the Kaffiøyra Plain vegetation. In the study area, the occurrence of character species of $L$. arcticae Gjærev. 1950 was recorded, namely L. ramulosa, Collema ceraniscum Nyl., Juncus biglumis, Blepharostoma trichophyllum (L.) Dumort., and Ditrichum flexicaule (Schwägr.) Hampe. Other character species for the association are M. biflora and D. crispula (Table 3). The presence of listed species led to the categorization of the vegetation of the Kaffiøyra Plain as M. biflora community (Table 2).

\section{Discussion}

Previous phytosociological studies were based on traditional, but diverse methods of plant community classification (Du Rietz 1930; Hadač 1946; Braun-Blanquet 1964); with such literature data, it is extremely difficult to create a uniform and transparent system in which described syntaxa will be hierarchically structured, unique, and representative for the entire Svalbard area. In the present study, historical data were subjected to modern numerical analyses, which confirmed several twentieth century syntaxa descriptions and aided the organization of the existing problematic phytosociological system.

The analyses confirmed the existence of two important distinct groups considered to be equal to alliances: the $L$. arcticae Gjærev. 1950 and the L. arcuatae Elvebakk ex Węgrzyn and Wietrzyk 2015 (Fig. 2), the character species of which are presented in Table 2 on the basis of the large values of fidelity. For the L. arcticae Gjærev. 1950, these are L. ramulosa, Distichium hagenii Ryan ex H. Philib., Blepharostoma trichophyllum, Distichium inclinatum (Hedw.) Bruch \& Schimp., Juncus biglumis, Luzula nivalis (Laest.) Spreng., Campylium polygamum (Schimp.) C.E.O. Jensen, Orthothecium strictum Lorentz, Pohlia cruda (Hedw.) Lindb., Collema ceraniscum, Pseudocalliergon turgescens (T. Jensen) Loeske, and Ditrichum flexicaule. For the L. arcuatae Elvebakk ex Węgrzyn and Wietrzyk 2015 these are Dicranum elongatum Schleich. ex Schwägr., Stereocaulon alpinum Laurer, Luzula confusa Lindeb., Aulacomnium turgidum (Wahlenb.) Schwägr., and Psoroma hypnorum (Vahl) Gray.

Gjærevoll (1950) considered the Luzulion arciticae Gjærev. 1950 to be the equivalent of the Luzulion nivalis Nordh. 1936. In the hierarchical classification of the plant communities of Spitsbergen proposed by Nilsen and Thannheiser (2013), the Luzulion nivalis Nordh. 1936 had a rank of suballiance (and belong to the alliances of the Saxifrago-Ranunculion nivalis Nordh. 1943 em. Dierßen 1984). However, the current work shows that this syntaxon should be raised again to the rank of alliance, due to its nature and distinctiveness of its species composition in comparison with the Saxifrago-Ranunculion nivalis Nordh. $1943 \mathrm{em}$. Dierßen 1984. It is worth noticing that the authorship of the description of this syntaxon is ambiguous: the publication of Nordhagen (1936) did not contain a description of the Luzulion nivalis Nordh. 1936; 
furthermore, the name of this alliance did not appear in this publication. However, (Nordhagen 1936) provides a description of an alpine association: the Ranunculo-Oxyrion Nordh. 1936, which probably corresponds to the arctic syntaxon called "Luzulion nivalis", as mentioned by Hadač (1989). The correct description of the alliance with the phytosociological data was available in Gjærevoll (1950) as L. arcticae. Luzula nivalis (Laest.) Spreng. is a synonym of Luzula arctica and the current name of the species (The Plant List 2013). However, we propose using the widely published name L. arcticae Gjærev. 1950 in order to prevent confusion (Weber et al. 2000).

Regarding the $L$. arcuatae Elvebakk ex Węgrzyn and Wietrzyk 2015, it was proposed as provisional name by Elvebakk (1985), although it had the rank of alliance and was equal to the following: the Cerastio-Saxifragion cernuae Hartm. 1980, the Saxifrago stellaris-Oxyrion digynae Gjærev. 1950 all. prov., and the Ranunculo-Oxyrion Nordh. 1936 p.p. in the hierarchical classification of the Spitsbergen plant communities (Nilsen and Thannheiser 2013). However, Nilsen and Thannheiser (2013) suggest the necessity of further research. Our studies showed the need for separation of the $L$. arcuatae Elvebakk ex Węgrzyn and Wietrzyk 2015 from other listed syntaxa. The first syntaxon, the Cerastio-Saxifragion cernuae Hartm. 1980, differed from L. arcuatae Elvebakk ex Węgrzyn and Wietrzyk 2015 not only in its character species, but also in a type of occupied habitat. The alliance described by Hartmann (1980) was appropriate only for ornithocoprophilous habitats located in near to bird cliffs, while the L. arcuatae Elvebakk ex Węgrzyn and Wietrzyk 2015 occurred in exposed ridge habitats. The species composition of the Saxifrago stellaris-Oxyrion digynae Gjærev. 1950 all. prov. strongly distinguished this syntaxon from the L. arcuatae Elvebakk ex Węgrzyn and Wietrzyk 2015. Moreover, various character species occurred in both alliances, such as Oxyria digyna and Saxifraga stellaris. The third syntaxon, the Ranunculo-Oxyrion Nordh. 1936, was similar to the L. arcticae Gjærev. 1950 in terms of its species composition, but not to the $L$. arcuatae Elvebakk ex Węgrzyn and Wietrzyk 2015.

The habitat analysis is also very important for ordering the alliances into the appropriate class. Our studies suggest that the L. arcticae Gjærev. 1950 and the L. arcuatae Elvebakk ex Węgrzyn and Wietrzyk 2015 belong to two different classes. The L. arcticae Gjærev. 1950 is assigned to the Salicetea herbaceae Br.-Bl. et al. 1947, which represents snowbed vegetation, as proposed by Elvebakk (1994) and Walker et al. (1994), and the L. arcuatae Elvebakk ex Węgrzyn and Wietrzyk 2015 was classified in the Thlaspietea rotundifolii Br.-Bl. et al. 1947, which includes plant communities of scree vegetation as indicated by Walker et al. (1994) and Nilsen and Thannheiser (2013).
Due to the similarity of alpine conditions to arctic ones, the alpine phytosociological classification was used to characterize the arctic vegetation (Gjærev. 1956; Dierßen 1984; Dahl 1987; Dierßen 1992). Originally, the Salicetea herbaceae Br.-Bl. et al. 1947 and the Thlaspietea rotundifolii Br.-Bl. et al. 1947 referred only to the alpine plant communities (Braun-Blanquet and Jenny 1926). Since that time, a floristic similarity of the plant communities belonging to both classes has been observed, especially in ecotone areas. Conducted analyses show the same situation in the Arctic where in analysed relevés there are species that are numerous and common in the species composition of both alliances, such as Saxifraga oppositifolia L., Cetrariella delisei (Bory ex Schaer.) Kärnefelt \& A. Thell, Brachythecium glaciale Schimp., Salix polaris Wahlenb., Ochrolechia frigida (Sw.) Lynge, Cerastium arcticum Lange, Saxifraga cernua L., Saxifraga cespitosa L., Polytrichastrum alpinum (Hedw.) G.L. Smith, and $\mathrm{Ce}$ traria islandica (L.) Ach. (Table 2). Furthermore, several of these species indicated that both syntaxa belong to the same type of vegetation-(G1) graminoid tundra (Walker et al. 2005).

Our syntaxonomic ordering is hierarchic and uses modern statistical analysis. In the existing phytosociology system (Elvebakk 1994) that characterizes the plant communities of snowbed and exposed ridge, there is a problem of synonymous associations and communities describing the same vegetation. Our classification is different from the one proposed by Elvebakk (1994). Plant communities assigned by Elvebakk (1994) to the L. arcticae Gjærev. 1950 are in our classification grouped into two associations and one community (Table 2; Fig. 3). Similarly, eight plant communities assigned by Elvebakk (1994) to the L. arcuatae Elvebakk ex Węgrzyn and Wietrzyk 2015 are grouped here into only two associations (Table 2; Fig. 3).

In terms of habitat, the $M$. biflora community and $P$. hirsutae ass. nov. refer to two successional types of tundra, as noted by Elvebakk (1979) and Hermansen (1979), but have never been described as associations. The M. biflora community is the earlier, initial stage, occurring on more humid, unregulated substrates, and it is dominated by bryophytes. This stage is dominant in the Kaffiøyra Plain, where the glacier rivers often erode the substrate. Despite our study, we decided not to give association rank to this community since it requires further investigation in the field. The association of $P$. hirsutae ass. nov. corresponds to the later successional stage with a higher proportion of lichens and vascular plants. This syntaxon occupies more stable and drier substrates; so it can be assumed that as the habitat is stabilizing and drying the M. biflora community is gradually replaced by the $P$. hirsutae ass. nov.

The D. alpinae (Nordh. 1943) Węgrzyn and Wietrzyk 2015 stat. nov. (Table 2) were described for the first time 
by Samuelsson (1916) and later revised by Nordhagen (1943). In the hierarchical classification of Spitsbergen plant communities (Nilsen and Thannheiser 2013), this syntaxon was assigned to the Cerastio-Saxifragion cernuae Hartm. 1980 (alliance equal to the L. arcuatae Elvebakk ex Węgrzyn and Wietrzyk 2015). The results of the current analyses indicate the necessity of moving the $D$. alpinae (Nordh. 1943) Węgrzyn and Wietrzyk 2015 stat. nov. to the L. arcticae Gjærev. 1950, due to the presence of character species of this alliance in the species composition of the association (Table 2). Moreover, this syntaxon occurs on oligotrophic substrates, in this case acidic and wet soils.

The A. juratzkanae Kobayashi ex Weggrzyn and Wietrzyk 2015 seems to be adequate to the Anthelia-Cesia-riche Luzula arcuata-Ass. Nordh. 1928. In the phytosociology classification of Nilsen and Thannheiser (2013), they refer to Nordhagen (1928), but published a different name of syntaxon: the Anthelio-Luzuletum arcuatae Nordh. 1928. However, Nordhagen (1928) did not contain information on the Anthelio-Luzuletum arcuatae, but included a description of Anthelia-Cesia-riche Luzula arcuata-Ass. Nordh. 1928. Despite the suggestions that the AntheliaCesia-riche Luzula arcuata-Ass. Nordh. 1928 and the Anthelio-Luzuletum arcuatae Nordh. 1928 are associations, they are insufficiently published according to the "International code of phytosociological nomenclature" (Weber et al. 2000). The A. juratzkanae Kobayashi 1988 prov. (Kobayashi et al. 1990) was a provisional name; according to our work, this name truly characterizes the described type of vegetation. In terms of habitat, the A. juratzkanae Kobayashi ex Węgrzyn and Wietrzyk 2015 covers scree areas with initial soils and because of that we assigned this association to the $L$. arcuatae Elvebakk ex Wegrzyn and Wietrzyk 2015.

The G. coralloidis Hadač ex Węgrzyn and Wietrzyk 2015 stat. nov. was not included in the classification of plant communities of Spitsbergen (Nilsen and Thannheiser 2013). Hadač (1946) assigned it to the order Salicetalia herbaceae Br.-Bl. ap. Br.-Bl. and Jenny 1926, but the current analyses show considerable similarity to the $L$. arcuatae Elvebakk ex Węgrzyn and Wietrzyk 2015 in terms of species composition and the presence of character species (Table 2). The substrate of this association is dry and composed of gravel and small pebbles (Dubiel and Olech 1990).

In these studies, we wished to draw attention to the possibility of using historical vegetation data to solve phytosociological problems faced by scientists who are trying to create a uniform system of plant community classification. To achieve this, modern numerical methods were used. In several cases, they confirmed the correctness of schemes proposed by cited authors, who described plant communities using traditional phytosociological methods.
However, our analyses have also led to the proposal of a new hierarchical classification of snowbed and exposed ridge plant communities of Svalbard and may hopefully for the foundation for revisions of syntaxa of other habitats.

Further to the hierarchical classification of plant communities of Spitsbergen elaborated by Nilsen and Thannheiser (2013), we would like to present, on the basis of our studies, the new classification of examined syntax as follows:

\section{Habitat: Snowbed}

Class: Salicetea herbaceae Br.-B1. et al. 1947

Order: Salicetalia herbaceae Br.-Bl.ap. Br.-Bl. and Jenny 1926

Alliance: Luzulion arcticae Gjærev. 1950

Association: Tomenthypnum involuti Hadač 1946

Association: Deschampsietum alpinae (Nordh. 1943) Węgrzyn and Wietrzyk 2015 stat. nov.

Association: Pedicularietum hirsutae Węgrzyn and Wietrzyk 2015 ass. nov.

Community: Minuartia biflora com.

\section{Habitat: Exposed ridge}

Class: Thlaspietea rotundifolii Br.-B1. et al. 1947

Order: Androsacetalia alpinae Br.-Bl. ap. Br.-Bl. and Jenny 1926

Alliance: Luzulion arcuatae Elvebakk ex Węgrzyn and Wietrzyk 2015

Association: Anthelietum juratzkanae Kobayashi ex Węgrzyn and Wietrzyk 2015

Association: Gymnomitrietum coralloidis Hadač ex Węgrzyn and Wietrzyk 2015 stat. nov.

Association: Sphaerophoro-Racomietum lanuginose (Hadač 1946; Hofm. 1968)

Association: Oxyrio-Trisetum spicati (Hadač 1946) Hadač 1989

Acknowledgments We are grateful to Dr. Ireneusz Sobota, the Station Leader of Nicolaus Copernicus University Polar Station, Kaffiøyra (NW Spitsbergen) for the permission to use the station, Marcin Nowak for help during fieldwork, Dr. Maciej Kozak (Institute of Botany, Jagiellonian University) for phytosociological advice, and Dr Beata Cykowska (Polish Academy of Science, Institute of Botany, Kraków) for determination of bryophytes. We are thankful to Prof. Mark Seaward (Department of Archaeological and Environmental Science, University of Bradford), Prof. Martin Bier (Department of Physics, East Carolina University; M. Smoluchowski Institute of Physics, Jagiellonian University), and Agnieszka Słaby (Institute of Botany, Jagiellonian University) for linguistic corrections and valuable improvements, and to Prof. Dietbert Thannheiser (University of Hamburg) for access to the literature. We also wish to thank anonymous reviewers for suggestions and remarks on our manuscript. 
Open Access This article is distributed under the terms of the Creative Commons Attribution 4.0 International License (http://creative commons.org/licenses/by/4.0/), which permits unrestricted use, distribution, and reproduction in any medium, provided you give appropriate credit to the original author(s) and the source, provide a link to the Creative Commons license, and indicate if changes were made.

\section{References}

Barkman JJ (1987) Preliminary investigations on the texture of high arctic tundra vegetation. In: Huiskes AHL, Blom CWPM, Rozema J (eds) Vegetation between land and sea. Junk, Dordrecht, pp 120-132

Brattbakk I (1979) Strandeng på Svalbard. Master's dissertation, Trondheim University

Brattbakk I (1980) Svalbards vegetasjon. K Norske Vidensk Selsk Rapp Bot Ser 5:55-72

Brattbakk I (1986) Flora og vegetasjon. In: Øritsland NA (ed) Svalbardreinen og dens livsgrunnlag. Universitetsforlaget, Oslo, pp 15-34

Braun-Blanquet J (1964) Pflanzensoziologie. Springer, Grundzüge der Vegetationskunde, p 865

Braun-Blanquet J, Jenny J (1926) Vegetations-Entwicklung und Bodenbildung in der alpinen Stufe der Zentralalpen. Denkschr Schweiz Naturforsch Ges 63:183-349

Braun-Blanquet J, Emberger L, Molinier R (1947) Instructions pour l'etablissement de la carte des groupements végétaux. Montpellier, Causse Graille Castelnau, pp 44

Brossard T, Deruelle S, Nimis PL, Petit P (1984) An interdisciplinary approach to vegetation mapping on lichen-dominated systems in high-arctic environment, Ny-Ålesund (Svalbard). Phytocoenologia 12:433-453. doi:10.1127/phyto/12/1984/433

Dahl E (1987) Alpine-subalpine plant communities of South Scandinavia. Phytocoenologia 15:455-484. doi:10.1127/phyto/15/1987/455

Dierßen K (1984) Vergleichende vegetationskundliche Untersuchungen an Schneeböden (Zur Abgrenzung der Klasse Salicetea herbaceae). Ber Dtsch Bot Ges 97:359-382. doi:10.1111/j.14388677.1984.tb03475.x

Dierßen K (1992) Zur Synsystematik nordeuropäischer Vegetationstypen. 1. Alpine Vegetation und floristisch verwandte Vegetationseinheiten tieferer Lagen sowie der Arktis. Ber ReinhTüxen Ges 4:191-226

Du Rietz GE (1930) The fundamental units of biological taxonomy. Svensk Bot Tidskr 24:333-428

Dubiel E, Olech M (1990) Plant communities of NW Sörkapp Land (Spitsbergen). Zesz Nauk Uniw Jagiell Prace Bot 21:35-74

Elton CS, Summerhayes VS (1928) Further contributions to the ecology of Spitsbergen. University Press, Cambridge, p 268

Elvebakk A. 1979. Plantesosiologi og fenelogi i eit arktisk område: Stuphallet, Brøggerhalvøya, Svalbard. Master's dissertation, Trondheim University

Elvebakk A (1985) Higher phytosociological syntaxa on Svalbard and their use in the subdivision of the Arctic. Nord J Bot 5:273-284. doi:10.1111/j.1756-1051.1985.tb01656.x

Elvebakk A (1994) A survey of plant associations and alliances from Svalbard. J Veg Sci 5:791-802. doi:10.2307/3236194

Elvebakk A (2005) A vegetation map of Svalbard on the scale 1:3.5mill. Phytocoenologia 35:951-967. doi:10.1127/0340269X/2005/0035-0951

Elvebakk A, Prestrud P (1996) A catalogue of Svalbard plants, fungi, algae and cyanobacteria. Norsk Polarinst Skr 198:1-395

Eurola S (1968) Über die Fjeldheidevegetation in den Gebieten von Isfjorden und Hornsund in Westspitzbergen. Aquilo Ser Bot $7: 1-56$
Gjærevoll O (1950) The snow-bed vegetation in the surroundings of Lake Torneträsk, Swedish Lapland. Svensk Bot Tidskr 1:387-440

Gjærevoll O (1956) The plant communities of the Scandinavian alpine snow-beds. I kommisjon hos F Bruns bokhandel, Trondheim, p 405

Gjessing YT, Øvstedal DO (1975) Energy budget and ecology of two vegetation types in Svalbard. Astarte 8:83-92

Hadač E (1946) The plant-communities of Sassen Quarter. Stud Bot Cechoslov 7:127-164

Hadač E (1989) Notes on plant communities of Spitsbergen. Folia Geobot Phytotax 24:1-169. doi:10.1007/BF02853039

Hartmann H (1980) Beitrag zur Kenntnis der Pflanzengesellschaften Spitzbergens. Phytocoenologia 8:65-147

Hennekens SM (2012) TURBOVEG for Windows. PDF: http://ibot. sav.sk/cdf/tvwin.pdf. Accessed 01 Mar 2014

Hermansen JE (1979) Vegetasjonsøkologi i et arktisk område, Brøggerhalvøya, Svalbard. Master's dissertation, Trondheim University

Hill MO, Gauch HG (1980) Detrended Correspondence analysis: an improved ordination technique. Vegetatio 42:47-58. doi:10. 1007/BF00048870

Hjelmstad R (1981) Flora—og vegetasjonsunders $ø$ kelser på Barentsøya. MAB i Norge-Svalbardprosjektet Rapp 8, Oslo, pp 46

Hofmann W (1968) Geobotanische Untersuchungen in SudostSpitzbergen. Ergebn Stauferland-Exped 1959/60 8:1-83

Jónsdóttir IS (2005) Terrestrial ecosystems on Svalbard: heterogeneity, complexity and fragility from an arctic island perspective. Proc R Irish Acad B 105:155-165. doi:10.3318/BIOE.2005.105.3.155

Kobayashi K, Kashiwadani H, Deguchi H (1990) Vegetation of Bohemanflyain Spitsbergen. In: Tatsumi T (ed) The Japanese scientific expeditions to Svalbard 1983-1988. Kyoikusha, Tokyo, pp 31-70

Lepš J, Smilauer P (2003) Multivariate analysis of ecological data using CANOCO. http://www.planta.cn/forum/files_planta/multi variate_analysis_of_ecological_data_using_canoco_390_173. pdf. Accessed 01 Mar 2014

Mattick F (1949) Die Flechten Spitzbergens. Polaforschung 19:261-273

Möller I (2000) Pflanzensoziologische und vegetationsökologische Studien in Nordwestspitzbergen. Hamburg, Mitt Geogr Ges Hamb (MGGH), p 226

Möller I, Thannheiser D (1997) Eine Vegetationsoase im unteren Mimerdalen am Billefjord, Zentral-Spitzbergen. Polarforschung 65:65-70

MycoBank (2014) MycoBank. http://www.mycobank.org/. Accessed 15 Mar 2014

Nilsen L, Thannheiser D (2013) Phytosociology of the Svalbard Archipelago including Bjørnøya and Jan Mayen. Arctic Vegetation Archive (AVA) Workshop, Krakow, Poland, April 14-16, 2013. CAFF Proc Rep 10:81-87

Nilsen L, Brossard T, Joly D, Elvebakk A (1999) Mapping and analysing arctic vegetation; evaluating a method coupling numerical classification of vegetation data with SPOT satellite data in a probability model. Int J Remote Sens 20:2947-2977. doi:10.1080/014311699211552

Nimis PL (1985) Structure and floristic composition of a high arctic tundra: Ny-Ålesund (Svalbard archipelago). Inter-Nord $17: 47-58$

Nordhagen R (1928) Die Vegetation und Flora des Sylenegebietes. I. Die Vegetation. Skr Nor Vidensk Akad Oslo I Mat-Naturv Kl $1: 1-612$

Nordhagen R (1936) Versuch einer neuen Einteilung der subalpinenalpinen Vegetation Norwegens. Berg Mus Årbok Naturvidensk R 7:1-88

Nordhagen R (1943) Sikilsdalens og Norges fjellbeiter. En plantesosiologisk monografi. Berg Mus Skr 22:1-607 
Olech M, Węgrzyn M, Lisowska M, Słaby A, Angiel P (2011) Contemporary changes in vegetation of polar regions. Papers on Global Change IGBP 18:35-51. doi:10.2478/v10190-010-0003-8

Philippi G (1973) Moosflora und Moosvegetation der Freeman-SundGebietes (Südost-Spitzbergen). Franz Steiner-Verlag, Wiesbaden, $\mathrm{p} 83$

Podani J (2001) SYN-TAX 2000. Computer programs for data analysis in ecology and systematics. User's manual. Budapest, Scientia, pp 53

Rønning OI (1965) Studies in Dryadion of Svalbard. Norsk Polarinst Skr 134:1-52

Rønning OI (1996) The flora of Svalbard. Oslo, Norsk Polarinst, p 184

Samuelsson G (1916) Studien uber die Entwicklungsgeschichte der Bluten einiger Bicornes-Typen. Ein Beitrag zur Kenntnis der systematischen Stellung der Diapensiaceen und Empetraceen. Svensk Bot Tidskr 7:97-188

Sobota I, Lankauf KR (2010) Recession of Kaffiøyra region glaciers, Oscar II Land, Svalbard. BG-PGS 3:27-45

Sokal RR, Michener CD (1958) A statistical method of evaluating systematic relationships. Univ Kans Sci Bull 28:1409-1438

Stow DA, Hope A, McGuire D, Verbyla D, Gamon JA, Huemmrich R et al (2004) Remote sensing of vegetation and land-cover change in arctic tundra ecosystems. Remote Sens Environ 89:281-308. doi:10.1016/j.rse.2003.10.018
The Plant List (2013) The Plant List. Version 1.1. http://www. theplantlist.org/. Accessed 13 Mar 2014

Tichý L, Holt J (2006) JUICE, program for management, analysis and classification of ecological data. http://www.sci.muni.cz/ botany/ juice/JUICEman_all.pdf. Accessed 1 Mar 2014

van der Maarel E (1979) Transformation of cover-abundance values in phytosociology and its effects on community similarity. Vegetatio 39:97-114. doi:10.1007/BF00052021

Walker MD, Daniëls FJ, van der Maarel E (1994) Circumpolar arctic vegetation. J Veg Sci 5:757-920. doi:10.1111/j.1654-1103.1994. tb00395.x

Walker DA, Raynolds MK, Daniëls FJ, Einarsson E, Elvebakk A, Gould WA et al (2005) The circumpolar Arctic vegetation map. J Veg Sci 16:267-282. doi:10.1111/j.1654-1103.2005.tb02365.x

Weber HE, Moravec J, Theurillat JP (2000) International code of phytosociological nomenclature. J Veg Sci 11:739-768. doi:10. $2307 / 3236580$

Węgrzyn M, Lisowska M, Olech M, Osyczka P (2011) Changes in vegetation. In: Ziaja W (ed) Transformation of the natural environment in Western Sørkapp Land (Spitsbergen) since the 1980s. Jagiellonian University Press, Kraków, pp 69-81 